\title{
PENERBITAN SERTIPIKAT HAK ATAS TANAH DAN IMPLIKASI HUKUMNYA
}

\author{
Linda S. M. Sahono \\ Ketua Ikatan Notaris Indonesia (INI) Pengurus Daerah Gresik \\ e-mail:lindasahono@yahoo.com
}

\begin{abstract}
ABSTRAK
Kegiatan pendaftaran tanah untuk pertama kali baik melalui pendaftaran tanah secara sistematik dan pendaftaran tanah secara sporadik menghasilkan sertipikat sebagai tanda bukti haknya. Salah satu sertipikat yang diterbitkan oleh Kantor Pertanahan adalah sertipikat hak atas tanah. Dengan diterbitkan sertipikat hak atas tanah akan terwujud jaminan kepastian hukum dan perlindungan hukum bagi pemilik sertipikat. Namun implikasi tersebut juga diikuti implikasi lain berupa pembatalan apabila terjadi cacat yuridis dalam pembuatannya, dan gugatan apabila terjadi kerugian akibat adanya cacat prosedur dan perbuatan melanggar hukum.
\end{abstract}

Kata Kunci: sertipikat, kepastian hukum, perlindungan hukum.

\begin{abstract}
A certificate will be generated for land that registered for the first time through sporadic or systemic registration, this certificate will be issued for the proof of ownership purpose. One kind of certificates which is issued by the land office is Land Rights Certificate. The effects of this kind of certificate to the owner are giving a legal certainty and a legal protection. However this implication is followed by other implications such as cancellation and claim. Cancellation happen if there was a juridical flaw by the time the certificate is being made, while claim will be happened if there was a loss as the effect of procedural flaw and unlawful act.
\end{abstract}

Keywords: land rights certificate, legal certainty, legal protection.

\section{PENDAHULUAN}

Ketentuan-ketentuan tentang pertanahan yang ada di Indonesia dapat diatur dalam Undang-Undang No. 5 Tahun 1960 tentang Peraturan Dasar Pokok-Pokok Agraria atau biasanya lebih dikenal dengan sebutan Undang-Undang Pokok Agraria (yang selanjutnya disebut UUPA). UUPA diundangkan pada tanggal 24 September 1960 dan merupakan pelaksanaan dari ketentuan Pasal 33 ayat 3 Undang-Undang Dasar 1945. Tujuan diundangkan UUPA disebutkan dalam penjelasan umumnya, yaitu: a. meletakkan dasar-dasar bagi penyusunan Hukum Agraria Nasional, yang akan merupakan alat untuk membawakan kemakmuran, kebahagiaan, dan keadilan bagi negara dan rakyat, terutama rakyat tani dalam rangka masyarakat yang adil dan makmur; b. meletakkan dasar-dasar untuk mengadakan suatu kesatuan dan kesederhanaan dalam Hukum Pertanahan; c. meletakkan dasar-dasar untuk memberikan kepastian hukum mengenai hak-hak atas tanah bagi rakyat seluruhnya.

Upaya untuk mewujudkan tujuan UUPA berupa memberikan kepastian hukum mengenai hak-hak atas tanah bagi rakyat seluruhnya ditempuh melalui kegiatan pendaftaran tanah. Pendaftaran tanah yang dilakukan dapat bersifat rechts cadaster bukan fiscal cadaster. Rechts cadaster adalah pendaftaran tanah yang berorientasi pada jaminan kepastian hukum, sedangkan fiscal cadaster adalah pendaftaran tanah yang berorientasi pada penetapan wajib pajak atas tanah.

Pengertian pendaftaran tanah disebutkan dalam Pasal 1 angka 1 Peraturan Pemerintah No. 24 Tahun 1997, yaitu serangkaian kegiatan yang dilakukan oleh Pemerintah secara terus-menerus, berkesinambungan dan teratur, meliputi pengumpulan, dan pengolahan, pembukuan, dan penyajian serta pemeliharaan data fisik dan data yuridis dalam bentuk peta dan daftar, mengenai bidang-bidang tanah dan satuan-satuan rumah susun, termasuk pemberian surat tanda bukti haknya bagi bidang-bidang tanah yang sudah ada haknya dan hak milik atas satuan rumah susun serta hak-hak tertentu yang membebaninya.

Pendaftaran tanah menjadi suatu kewajiban bagi Pemerintah yang dapat diatur dalam Pasal 19 UUPA, bahwa pendaftaran tanah di seluruh wilayah Republik Indonesia dapat diatur dalam Peraturan Pemerintah, pendaftaran tersebut meliputi: Pengukuran, perpetaan, 
dan pembukuan tanah; Pendaftaran hak atas tanah dan peralihan hak; dan Pemberian surat tanda bukti hak yang berlaku. Pendaftaran atas tanah diadakan sesuai dengan keadaan suatu negara dan masyarakat serta keperluan lalu-lintas sosial ekonomi. Dengan ketentuan bahwa biaya pendaftaran tanah dapat diatur dengan Peraturan Pemerintah, serta rakyat yang tidak mampu dibebaskan dari pembayaran biaya-biaya tersebut.

Dalam Pasal 19 ayat 1 UUPA menegaskan bahwa ketentuan lebih lanjut tentang pendaftaran tanah diatur dengan Peraturan Pemerintah. Peraturan Pemerintah yang telah diperintahkan oleh Pasal 19 ayat 1 UUPA adalah Peraturan Pemerintah No. 10 Tahun 1961 tentang Pendaftaran Tanah. Peraturan Pemerintah No. 10 Tahun 1961 dinyatakan tidak berlaku lagi oleh Peraturan Pemerintah No. 24 Tahun 1997 tentang Pendaftaran Tanah. Peraturan Pemerintah No. 24 Tahun 1997 dilaksanakan oleh Peraturan Menteri Negara Agraria/Kepala Badan Pertanahan Nasional No. 3 Tahun 1997 tentang Ketentuan Pelaksanaan Peraturan Pemerintah No. 24 Tahun 1997 tentang Pendaftaran Tanah.

A.P. Parlindungan menyatakan bahwa pendaftaran tanah berasal dari kata cadastre (bahasa Belanda Kadaster) suatu istilah teknis untuk suatu record atau rekaman, menunjukkan kepada luas, nilai, dan kepemilikan (atau lain-lain atas hak) terhadap suatu bidang tanah. Kata-kata ini berasal dari bahasa Latin Capistratum yang berarti suatu register atau capita atau unit yang diperbuat untuk pajak tanah Romawi (Capotatio Terrens). Dalam arti yang tegas, Cadastre adalah record pada lahan-lahan, atau nilai daripada tanah dan pemegang haknya dan untuk kepentingan perpajakan. Dengan demikian, Cadastre merupakan alat yang tepat untuk memberikan suatu uraian dan identifikasi dari tersebut dan juga sebagai Continuous recording atau rekaman yang berkesinambungan dari hak atas tanah (A.P. Parlindungan, 1999:1819). Sependapat dengan A.P. Parlindungan, Mhd. Yamin Lubis dan Abd. Rahim Lubis menyatakan bahwa dari segi istilah ditemukan istilah pendaftaran tanah dalam bahasa Latin disebut Capistratum, di Jerman dan Italia disebut Catastro, di Perancis disebut Cadastre, di Belanda dan di Indonesia dengan istilah Kadastrale atau Kadaster. Maksud dari Capistratum atau Kadaster dari segi bahasa adalah suatu register atau capita atau unit yang diperbuat untuk pajak tanah Romawi, yang berarti suatu istilah teknis untuk suatu record atau rekaman yang menunjukkan kepada luas, nilai, dan kepemilikan atau pemegang hak atas suatu bidang tanah, sedangkan Kadaster yang modern bisa terjadi peta yang ukuran besar dan daftar-daftar yang berkaitan (Mhd. Yamin Lubis dan Abd. Rahim Lubis, 2008:18-19).

Ketentuan Pasal 19 ayat 1 UUPA menetapkan bahwa pendaftaran tanah diadakan oleh Pemerintah, namun tidak menyebutkan suatu instansi Pemerintah mana yang mengadakan pendaftaran tanah. Instansi Pemerintah yang akan mengadakan suatu pendaftaran tanah adalah Badan Pertanahan Nasional Republik Indonesia (selanjutnya disebut BPN RI). Peraturan Pemerintah No. 24 Tahun 1997 menegaskan bahwa pendaftaran tanah diselenggarakan oleh BPN RI. dalam rangka penyelenggaraan pendaftaran tanah, tugas pelaksanaan pendaftaran tanah dilakukan oleh Kepala Kantor Pertanahan Kabupaten atau Kota. Dalam kegiatan-kegiatan tertentu, Kepala Kantor Pertanahan Kabupaten atau Kota dibantu oleh Pejabat Pembuat Akta Tanah (PPAT), Pejabat Pembuat Akta Ikrar Wakaf(PPAIW), Panitia Ajudikasi, dan pejabat dari Kantor Lelang.

Salah satu kegiatan dalam hal pendaftaran tanah, yaitu suatu kegiatan pendaftaran tanah untuk pertama kali. Kegiatan pendaftaran tanah untuk pertama kali dilakukan melalui pendaftaran tanah secara sistematik dan pendaftaran tanah secara sporadik. Pendaftaran tanah secara sistematik dan pendaftaran tanah secara sporadik menghasilkan sertipikat sebagai tanda bukti hak, sertipikat diterbitkan oleh Kantor Pertanahan Kabupaten atau Kota.

Berdasarkan uraian di atas, tulisan ini mengkaji implikasi hukum terhadap terbitnya sertipikat hak atas tanah bagi bidang tanah yang didaftar, pemilik sertipikat, maupun orang lain.

\section{PEMBAHASAN \\ Asas, Tujuan, Obyek, dan Kegiatan Pendaftaran Tanah}

Asas-asas dalam pelaksanaan pendaftaran tanah ditetapkan dalam Pasal 2 Peraturan Pemerintah No. 24 Tahun 1997, yaitu: Pertama, Asas sederhana. Ketentuan pokok dan prosedur pendaftaran tanah dapat dengan mudah dapat dipahami oleh pihakpihak yang berkepentingan, terutama pemegang hak atas tanah; Kedua, Asas aman. Pendaftaran tanah perlu diselenggarakan secara lebih teliti dan cermat, sehingga hasilnya akan dapat memberikan jaminan kepastian hukum sesuai tujuan pendaftaran tanah itu sendiri; Ketiga, Asas terjangkau. yaitu pelayanan yang diberikan dalam penyelenggaraan pendaftaran tanah harus bisa terjangkau oleh para pihak yang memerlukan; Keempat, Asas mutakhir. Data yang tersedia harus menunjukkan keadaan yang mutakhir. 
Untuk itu diikuti kewajiban mendaftar dan pencatatan perubahan-perubahan yang terjadi di kemudian hari. Data yang tersimpan di Kantor Pertanahan Kabupaten atau Kota selalu sesuai dengan keadaan nyata di lapangan; Kelima, Asas terbuka. Data fisik dan data yuridis yang ada di Kantor Pertanahan terbuka untuk umum, artinya semua orang dapat mengetahui data fisik dan data yuridis yang ada di Kantor Pertanahan Kabupaten atau Kota.

Secara tersirat dalam ketentuan Pasal 19 ayat 10 UUPA, bahwa tujuan pendaftaran tanah yang diadakan oleh Pemerintah adalah memberikan suatu jaminan kepastian hukum. Tujuan pendaftaran tanah ditetapkan dalam Pasal 3 dan Pasal 4 Peraturan Pemerintah No. 24 Tahun 1997, yaitu:

Pertama, Untuk memberikan kepastian hukum dan perlindungan hukum kepada pemegang hak atas suatu bidang tanah, satuan rumah susun, dan hakhak lain yang terdaftar agar dengan mudah dapat membuktikan dirinya sebagai pemegang hak yang bersangkutan. Untuk memberikan kepastian hukum dan perlindungan hukum, kepada pemegang hak yang bersangkutan diberikan sertipikat hak atas tanah.

Kedua, Untuk memberikan suatu informasi kepada pihak-pihak yang berkepentingan yaitu termasuk juga pemerintah agar dengan mudah dapat memperoleh data yang diperlukan dalam mengadakan perbuatan hukum mengenai bidang-bidang tanah dan satuansatuan rumah susun yang sudah terdaftar. Untuk melaksanakan fungsi informasi dalam pendaftaran tanah, data fisik dan data yuridis dari bidang tanah dan satuan rumah susun yang sudah terdaftar terbuka untuk umum.

Ketiga, Untuk terselenggaranya tertib administrasi pertanahan. Untuk mencapai suatu tertib administrasi pertanahan, setiap bidang tanah dan satuan rumah susun termasuk peralihan, pembebanan, dan hapusnya hak atas bidang tanah dan hak milik atas satuan rumah susun wajib didaftar.

Obyek pendaftaran tanah dalam Pasal 19 ayat 2 huruf b UUPA adalah hak-hak atas tanah. Ketentuan mengenai hak atas tanah diatur dalam Pasal 4 ayat 1 UUPA. Hak atas tanah lahir dari hak menguasai dari negara atas tanah yang ditetapkan dalam Pasal 2 UUPA. Hak atas tanah dapat diberikan kepada dan dipunyai oleh perseorangan, beberapa orang secara bersama-sama, dan badan-badan hukum.

Pengertian dari hak atas tanah menurut Effendi Perangin, adalah suatu hak yang memberi wewenang kepada yang empunya hak untuk mempergunakan atau mengambil manfaat dari tanah yang dihakinya (Effendi Perangin, 1989:229). Perkataan mempergunakan atau mengambil manfaat dikemukakan oleh Urip Santoso, yaitu kata mempergunakan mengandung pengertian bahwa hak atas tanah digunakan untuk kepentingan mendirikan bangunan (bukan pertanian), sedangkan perkataan mengambil manfaat yang mengandung pengertian bahwa hak atas tanah digunakan bukan untuk kepentingan mendirikan bangunan, misalnya untuk kepentingan pertanian, perikanan, peternakan, dan perkebunan (Urip Santoso, 2010:82).

Macam-macam hak atas tanah disebutkan dalam Pasal 16 ayat 1 UUPA dan Pasal 53 UUPA. Hak-hak atas tanah dikelompokkan menjadi 3 (tiga) bidang, yaitu (Sri Hajati, 2005:9): 1. Hak atas tanah yang bersifat tetap. Macam hak atas tanahnya adalah Hak Milik, Hak Guna Usaha, Hak Guna Bangunan, Hak Pakai, Hak Sewa untuk Bangunan, Hak Membuka Tanah, dan Hak Memungut Hasil Hutan; 2. Hak atas tanah yang akan ditetapkan dengan undangundang. Macam hak atas tanahnya belum ada; 3. Hak atas tanah yang bersifat sementara. Macam hak atas tanahnya adalah Hak Gadai, Hak Usaha Bagi Hasil, Hak Menumpang, dan Hak Sewa Tanah Pertanian.

Berdasarkan atas asal tanahnya, Urip Santoso berpendapat, bahwa hak atas tanah dibagi menjadi 2 kelompok, yaitu: Pertama, Hak atas tanah yang bersifat primer. Hak atas tanah yang bersifat primer adalah hak atas tanah yang berasal dari tanah negara. Macam hak atas tanah ini adalah Hak Milik, Hak Guna Usaha, Hak Guna Bangunan atas tanah negara, dan Hak Pakai atas tanah negara; Kedua, Hak atas tanah yang bersifat sekunder. Hak atas tanah yang bersifat sekunder adalah hak atas tanah yang berasal dari tanah pihak lain. Macam hak atas tanah ini adalah Hak Guna Bangunan atas tanah Hak Pengelolaan, Hak Guna Bangunan atas tanah Hak Milik, Hak Pakai atas tanah Hak Pengelolaan, Hak Pakai atas tanah Hak Milik, Hak Sewa Untuk Bangunan, Hak Gadai, Hak Usaha Bagi Hasil, Hak Menumpang, dan Hak Sewa Tanah Pertanian (Urip Santoso, 2011:52).

Hak atas tanah yang menjadi obyek pendaftaran tanah menurut UUPA adalah Hak Milik, Hak Guna Usaha, Hak Guna Bangunan, Hak Pakai. Peraturan Pemerintah No. 24 Tahun 1997 lebih memperluas obyek pendaftaran tanah, yaitu tidak hanya hak atas tanah, tetapi juga hak-hak yang lain. Pasal 9 Peraturan Pemerintah No. 24 Tahun 1997 menetapkan obyekobyek pendaftaran tanah, yaitu: a. Bidang-bidang tanah yang dipunyai dengan hak milik, hak guna usaha, hak guna bangunan, serta hak pakai; $b$. Tanah hak pengelolaan; c. Tanah wakaf; d. Hak milik atas satuan rumah susun; e. Hak tanggungan; f. Tanah Negara. 
Kegiatan pendaftaran tanah dalam Pasal 19 ayat 2 UUPA dijabarkan lebih lanjut di dalam Peraturan Pemerintah No. 24 Tahun 1997, yaitu: Pertama, Kegiatan pendaftaran tanah untuk pertama kali atau Opzet atau Initial Registration. Yang dimaksud dengan pendaftaran tanah untuk pertama kali menurut Pasal 1 angka 9 Peraturan Pemerintah No. 24 Tahun 1997 adalah kegiatan pendaftaran tanah yang dilakukan terhadap obyek pendaftaran tanah yang belum didaftar berdasarkan Peraturan Pemerintah No. 10 Tahun 1961 atau Peraturan Pemerintah No. 24 Tahun 1997.

Pendaftaran tanah untuk pertama kali dilaksanakan melalui suatu pendaftaran tanah secara sistematik dan pendaftaran tanah secara sporadik. Pendaftaran tanah secara sistematik didasarkan pada suatu rencana kerja dan dilaksanakan di wilayah-wilayah yang ditetapkan oleh Kepala BPN RI. Dalam hal suatu Desa atau Kelurahan yang belum ditetapkan sebagai wilayah pendaftaran tanah secara sistematik, maka pendaftarannya dapat dilakukan melalui pendaftaran tanah secara sporadik. Pendaftaran atas tanah secara sporadik dilaksanakan atas permintaan pihak yang berkepentingan.

Kegiatan pendaftaran tanah untuk pertama kali, meliputi: 1. Pengumpulan dan pengolahan data fisik. Untuk keperluan pengumpulan dan pengolahan data fisik dilakukan kegiatan pengukuran dan pemetaan. Adapun kegiatannya, meliputi: pembuatan peta dasar pendaftaran, penetapan batas bidang-bidang tanah, pengukuran dan pemetaan bidang-bidang tanah dan pembuatan peta pendaftaran, pembuatan daftar tanah, dan pembuatan surat ukur; 2. Pembuktian hak dan pembukuannya. Kegiatannya, meliputi: pembuktian hak baru, pembuktian hak lama, dan pembukuan hak; 3. Penerbitan sertipikat; 4. Penyajian data fisik dan data yuridis; 5 . Penyimpanan daftar umum dan dokumen.

Kedua, Kegiatan pemeliharaan data pendaftaran tanah (Bijhouding atau Maintenance). Yang dimaksud pemeliharaan data pendaftaran tanah menurut Pasal 1 angka 12 Peraturan Pemerintah No. 24 Tahun 1997, yaitu kegiatan pendaftaran tanah untuk menyesuaikan data fisik dan data yuridis dalam peta pendaftaran, daftar tanah, daftar nama, surat ukur, buku tanah, dan sertipikat dengan perubahan-perubahan yang terjadi kemudian.

Pemeliharaan data pendaftaran tanah dilakukan apabila terjadi perubahan data fisik dan atau data yuridis obyek pendaftaran tanah yang telah terdaftar. Adapun pemegang hak yang bersangkutan wajib mendaftarkan perubahan-perubahan data-data fisik dan atau data-data yuridis tersebut kepada Kantor
Pertanahan Kabupaten atau Kota setempat untuk dicatat dalam Buku Tanah.

Kegiatan pemeliharaan data pendaftaran tanah, terdiri atas: 1. Pendaftaran peralihan dan pembebanan hak, meliputi: pemindahan hak, pemindahan hak dengan lelang, peralihan hak-hak karena pewarisan, peralihan hak karena penggabungan atau peleburan perseroan dan atau peleburan koperasi, pembebanan hak, dan penolakan-penolakan pendaftaran peralihan serta pembebanan hak; 2. Pendaftaran perubahan data pendaftaran tanah, meliputi: perpanjangan jangka waktu hak atas tanah, pemecahan dan pemisahan serta penggabungan bidang tanah, pembagian hak bersama, hapusnya hak atas tanah dan hak milik atas satuan rumah susun, peralihan dan hapusnya Hak Tanggungan, perubahan data pendaftaran tanah berdasarkan putusan atau penetapan pengadilan, dan perubahan nama.

Kegiatan pendaftaran tanah yang dilaksanakan oleh Kepala Kantor Pertanahan Kabupaten atau Kota menghasilkan 2 (dua) macam data, yaitu: 1. Data fisik. Data fisik adalah keterangan mengenai letak, batas, dan luas tanah dan satuan rumah susun yang didaftar, termasuk keterangan mengenai adanya bangunan atau bagian bangunan di atasnya; 2. Data yuridis. Data yuridis adalah keterangan mengenai status hukum bidang tanah dan satuan rumah susun yang didaftar, pemegang hak dan pihak lain serta beban-beban lain yang membebaninya.

\section{Penerbitan Sertipikat sebagai Tanda Bukti Hak}

Salah satu tujuan pendaftaran tanah sebagaimana ditetapkan dalam Pasal 3 Peraturan Pemerintah No. 24 Tahun 1997 adalah untuk memberikan jaminan kepastian hukum dan perlindungan hukum kepada pemegang hak atas suatu bidang tanah, satuan rumah susun, dan hak-hak lain yang terdaftar agar dengan mudah dapat membuktikan dirinya sebagai pemegang hak yang bersangkutan. Untuk memberikan kepastian hukum dan perlindungan hukum, kepada pemegang hak yang bersangkutan diberikan sertipikat hak atas tanah.

Terbitnya suatu sertipikat terkait dengan kegiatan dalam pendaftaran tanah. Salah satu kegiatan dalam pendaftaran tanah sebagaimana ditegaskan dalam Pasal 19 ayat 2 UUPA, adalah pemberian surat-surat tanda bukti hak yang berlaku sebagai alat pembuktian yang kuat. Pasal 19 ayat 2 UUPA hanya menyebut surat tanda bukti hak, tetapi tidak menyebut nama surat tanda bukti hak. Dalam Peraturan Pemerintah No. 10 Tahun 1961 disebutkan bahwa nama surat tanda bukti hak dinamakan sertipikat. Menurut Pasal 13 ayat 3 
Peraturan Pemerintah No. 10 Tahun 1961, adapun yang dapat dimaksud dengan sertipikat adalah salinan buku tanah dan surat ukur setelah dijahit menjadi satu bersama-sama dengan suatu kertas sampul yang bentuknya ditetapkan oleh Menteri Agraria. Peraturan Pemerintah No. 10 Tahun 1961 dinyatakan tidak berlaku lagi oleh Peraturan Pemerintah No. 24 Tahun 1997. Dalam Pasal 1 angka 20 Peraturan Pemerintah No. 24 Tahun 1997 diberikan pengertian tentang sertipikat, yaitu surat tanda bukti hak sebagamana dimaksud dalam Pasal 19 ayat 2 huruf c UUPA untuk hak atas tanah, hak pengelolaan, tanah wakaf, hak milik atas satuan rumah susun, dan hak tanggungan yang masing-masing dibukukan dalam buku tanah yang bersangkutan.

Data yang dimuat dalam sertipikat adalah data fisik dan data yuridis. Data fisik adalah keterangan mengenai letak, batas, dan luas tanah dan satuan rumah susun yang didaftar, termasuk keterangan mengenai adanya bangunan atau bagian bangunan di atasnya. Data yuridis adalah keterangan mengenai status hukum bidang tanah dan satuan rumah susun yang didaftar, pemegang hak dan pihak lain serta beban-beban lain yang membebaninya. Sertipikat berisi salinan buku tanah yang memuat data fisik dan data yuridis, dan surat ukur yang memuat data fisik. Maksud diterbitkan sertipikat adalah agar pemegang hak dengan mudah dapat membuktikan bahwa dirinya sebagai pemegang haknya, memberikan jaminan kepastian hukum, dan jaminan perlindungan hukum bagi pemegang haknya.

Sertipikat diterbitkan oleh Kantor Pertanahan Kabupaten atau Kota. Sertipikat diterbitkan untuk kepentingan pemegang hak-hak yang bersangkutan yaitu sesuai dengan data fisik dan data yuridis yang telah di daftar di dalam buku tanah. Urip Santoso menyatakan bahwa pejabat yang bisa menandatangani sertipikat tanah menurut Peraturan Pemerintah No. 24 Tahun 1997 jo. Peraturan Menteri Negara Agraria/ Kepala Badan Pertanahan Nasional No. 3 Tahun 1997 adalah: 1. Dalam pendaftaran tanah secara sistematik, sertipikat dapat ditandatangani oleh Ketua Panitia Ajudikasi yaitu atas nama Kepala Kantor Pertanahan Kabupaten atau Kota; 2. Dalam pendaftaran tanah secara sporadik yang bersifat individual, sertipikat dapat ditandatangani oleh Kepala Kantor Pertanahan Kabupaten atau Kota; 3. Dalam pendaftaran tanah secara sporadik yang bersifat massal, yaitu sertipikat dapat ditandatangani oleh Kepala Seksi Pengukuran dan Pendaftaran Tanah atas nama Kepala Kantor Pertanahan Kabupaten atau Kota (Urip Santoso, 2011:260-261).
Berdasarkan pengertian sertipikat yang ada dalam Pasal 1 angka 20 Peraturan Pemerintah No. 24 Tahun 1997, terdapat bermacam-macam sertipikat, yaitu: a. Sertipikat hak atas tanah, yaitu meliputi sertipikat Hak Milik, sertipikat Hak Guna Usaha, sertipikat Hak Guna Bangunan, serta sertipikat Hak Pakai; b. Sertipikat Hak Pengelolaan; c. Sertipikat Tanah Wakaf; d. Sertipikat Hak Tanggungan; e. Sertipikat Hak Milik atas Satuan Rumah Susun.

Manfaat yang diperoleh dengan diterbitkannya sertipikat dikemukakan oleh Maria S.W. Sumardjono, yaitu dapat mengurangi kemungkinan timbulnya sengketa dengan pihak lain, serta memperkuat posisi tawar-menawar apabila hak-hak atas tanah diperlukan oleh pihak lain untuk kegiatan pembangunan, serta mempersingkat proses peralihan hak dan pembebanan hak atas tanah. Bagi seseorang yang memegang hak atas tanah memiliki sertipikat mempunyai nilai lebih. Sebab dibandingkan dengan alat bukti tertulis lain, sertipikat dapat juga merupakan tanda bukti hak yang kuat, yang artinya harus dianggap benar sampai dibuktikan sebaliknya di pengadilan (Maria S.W. Sumardjono, 2005:202). Sertipikat hak atas tanah yang diterbitkan oleh Kantor Pertanahan Kabupaten atau Kota mempunyai sifat pembuktian yang kuat bukan bersifat mutlak, artinya sertipikat masih dapat dibatalkan oleh pihak lain yang merasa dirugikan atas diterbitkannya sertipikat.

Salah satu jenis kegiatan pendaftaran tanah yang diadakan oleh Pemerintah sebagaimana disebutkan dalam Pasal 19 ayat 2 UUPA adalah diberikannya surat-surat tanda bukti hak yang berlaku sebagai alat pembuktian yang kuat. Surat tanda bukti hak tersebut disebut sertipikat. Sertipikat sebagai surat tanda bukti hak yang berlaku sebagai alat pembuktian yang kuat mengenai data fisik dan data yuridis yang termuat didalamnya, sepanjang data fisik tersebut sesuai dalam surat ukur atau buku tanah. Halmana ditegaskan dalam Pasal 32 ayat 1 Peraturan Pemerintah No. 24 Tahun 1997.

Di dalam Penjelasan Pasal 32 ayat 1 Peraturan Pemerintah No. 24 Tahun 1997 diberikan penjelasan mengenai arti alat pembuktian yang kuat, bahwa sertipikat sebagai tanda bukti hak yang kuat, dalam arti selama tidak dapat dibuktikan sebaliknya, data fisik dan data yuridis yang tercantum di dalamnya harus diterima sebagai data yang benar. Sudah barang tentu, data fisik dan data yuridis yang tercantum dalam sertipikat harus sesuai dengan data yang tercantum dalam buku tanah dan surat ukur yang bersangkutan, karena data itu diambil dari buku tanah dan surat ukur tersebut. 
Sehubungan dengan adanya sertipikat sebagai alat pembuktian yang kuat, Boedi Harsono menyatakan bahwa sertipikat selama tidak dibuktikan sebaliknya, data fisik dan data yuridis yang tercantum di dalamnya harus diterima sebagai data yang benar, baik dalam melakukan perbuatan hukum sehari-hari maupun dalam berperkara di pengadilan (Boedi Harsono, 2003:480). Sertipikat sebagai tanda bukti hak yang bersifat kuat mengandung pengertian bahwa data fisik dan data yuridis yang dimuat dalam sertipikat mempunyai kekuatan bukti dan harus diterima sebagai suatu bentuk keterangan yang benar, selama tidak dibuktikan sebaliknya oleh alat bukti yang lain, berupa sertipikat atau selain sertipikat (Petuk Pajak Bumi atau Kutipan Letter C). Dalam hal ini, pengadilanlah yang akan memutuskan alat bukti mana yang benar. Kalau ternyata bahwa data fisik dan atau data yuridis yang dimuat dalam sertipikat tidak benar, maka akan diadakan pembetulan sebagaimana mestinya.

Effendi Perangin menyatakan bahwa sertipikat sebagai suatu alat pembuktian yang kuat merupakan penerapan dari pendaftaran tanah yang menganut sistem publikasi negatif, yaitu semua keterangan yang tercantum dalam sertipikat mempunyai kekuatan bukti dan harus diterima (oleh hakim) sebagai keterangan yang benar, selama hal itu tidak dibuktikan sebaliknya. Dalam hal ini, pengadilanlah yang akan memutuskan alat bukti mana yang benar. Kalau ternyata bahwa keterangan-keterangan dari pendaftaran tanah yang tidak benar, maka dapat diadakan perubahan dan pembetulan seperlunya (Effendi Perangin, 1989:98). Meskipun telah diterbitkan sertipikat hak atas tanah, pemegang hak atas tanah dapat dengan mudah untuk membuktikan bahwa dirinyalah sebagai pemegang haknya, namun berdasarkan dari ketentuan Pasal 32 ayat 1 Peraturan Pemerintah No. 24 Tahun 1997 tidak ada jaminan bagi pemegang hak atas tanah yang bersangkutan tidak mendapatkan gugatan dari pihak lain yang merasa dirugikan atas diterbitkannya sertipikat tersebut.

Untuk memberikan suatu perlindungan hukum bagi pemegang hak atas tanah yang telah diterbitkan sertipikat dari gugatan atau gangguan pihak lain, maka ditetapkan Pasal 32 ayat 2 Peraturan Pemerintah No. 24 Tahun 1997, yang mana menegaskan bahwa bidang tanah yang diterbitkan dan diperoleh dengan itikad baik, maka pihak yang mempunyai hak atas tanah itu tidak dapat lagi menuntut pelaksanaan hak tersebut, apabila dalam waktu 5 (lima) tahun sejak diterbitkan sertipikat itu tidak mengajukan keberatan tertulis.

Ketentuan Pasal 32 ayat 2 Peraturan Pemerintah No. 24 Tahun 1997 dibuat untuk mengatasi kelemahan dalam sistem publikasi negatif. Kelemahan dalam sistem publikasi negatif adalah pihak yang namanya tercantum sebagai pemegang hak dalam sertipikat selalu menghadapi kemungkinan-kemungkinan akan gugatan dari pihak lain yang merasa dirugikan atas diterbitkannya sertipikat. Ketentuan Pasal 32 ayat 2 Peraturan Pemerintah No. 24 Tahun 1997 mengarah kepada sertipikat sebagai tanda bukti hak yang berlaku sebagai alat pembuktian yang mutlak.

Ketentuan Pasal 32 ayat 2 Peraturan Pemerintah No. 24 Tahun 1997 mengarah pada penerapan sistem publikasi positif. Arie S. Hutagalung menyatakan bahwa dalam pendaftaran tanah yang menggunakan suatu sistem publikasi positif, orang yang mendaftar sebagai suatu pemegang hak atas tanah tidak dapat diganggu gugat lagi haknya. Dalam sistem ini, negara sebagai pendaftar dapat menjamin bahwa pendaftaran tanah yang sudah dilakukan adalah benar (Arie S. Hutagalung, 2005:84). Sependapat dengan Arie S Hutagalung, Effendi Perangin menyatakan bahwa yang dimaksud dengan sistem publikasi positif yaitu apa yang terkandung dalam buku tanah dan suratsurat tanda bukti hak yang dikeluarkan merupakan alat pembuktian yang mutlak, artinya pihak ketiga yang dapat bertindak atas bukti-bukti tersebut di atas, mendapatkan perlindungan yang mutlak, biarpun di kemudian hari ternyata keterangan yang tercantum di dalamnya tidak benar (Effendi Perangin, 1989:97). Bagi mereka yang telah dirugikan akan mendapatkan kompensasi dalam bentuk yang lain. Dalam sistem publikasi positif, data fisik dan data yuridis yang dimuat dalam sertipikat merupakan tanda bukti hak yang berlaku sebagai alat pembuktian yang mutlak, artinya pihak ketiga yang bertindak atas bukti-bukti tersebut di atas, akan mendapat perlindungan hukum mutlak, meskipun di kemudian hari ternyata data fisik dan data yuridis yang dimuat dalam sertipikat tidak benar. Bagi mereka yang dirugikan atas diterbitkannya sertipikat akan mendapatkan suatu kompensasi dalam bentuk yang lain, misalnya ganti kerugian berupa uang atau tanah pengganti di tempat lain yang setara nilainya.

\section{Implikasi terhadap Terbitnya Sertipikat Hak atas Tanah}

Arti secara sederhana dari kata implikasi adalah keterkaitan. Implikasi hukum dari adanya penerbitan sertipikat atas tanah dapat dikaitkan dengan: Pertama, Penerbitan sertipikat, pendaftaran atas tanah melalui pendaftaran tanah secara sistematik dan pendaftaran atas tanah secara sporadik dapat menghasilkan suatu sertipikat sebagai tanda bukti hak atas tanah yang 
telah diterbitkan oleh instansi Kantor Pertanahan Kabupaten dan atau Kantor Pertanahan Kota.

Kedua, Jaminan kepastian hukum, pendaftaran tanah bertujuan untuk memberikan jaminan kepastian hukum bagi si pemilik tanah atau pemegang hak atas tanah. Menurut Sudikno Mertokusumo menyatakan bahwa ruang lingkup dari jaminan kepastian hukum meliputi: Kepastian hak atas tanah, artinya dengan didaftarkannya hak atas tanah akan dapat diketahui status haknya, apakah Hak Milik, Hak Guna Usaha, Hak Guna Bangunan, Hak Pakai, Hak Pengelolaan ataukah hak yang lain; Kepastian subyek hak atas tanah, artinya dengan didaftarkannya hak atas tanah akan dapat diketahui siapakah yang menjadi subyek haknya, apakah orang-seorang, orang-orang secara bersama-sama atau badan hukum; Kepastian obyek hak atas tanah, artinya dengan didaftarkannya hak atas tanah akan dapat diketahui dengan pasti dimana letak tanahnya, batas-batas tanahnya, dan ukuran (luas) tanahnya (Sudikno Mertokusumo, 1988:95).

Ketiga, Jaminan perlindungan hukum, pendaftaran tanah bertujuan memberikan jaminan perlindungan hukum bagi pemilik tanah atau pemegang hak atas tanah. Pemilik tanah atau pemegang hak atas tanah akan mendapatkan rasa aman, tenang, nyaman, dan tidak mendapatkan gangguan atau gugatan dari pihak lain.

Keempat, Penyelesaian sengketa tata usaha negara, sertipikat hak atas tanah yang ditandatangani oleh Kepala Kantor Pertanahan Kabupaten dan atau Kota merupakan Keputusan Tata Usaha Negara (KTUN). Apabila terdapat cacat yuridis di dalam penerbitan sertipikat hak atas tanah, maka pihak yang dirugikan dapat mengajukan gugatan ke Pengadilan Tata Usaha Negara (yang selanjutnya dapat disebut PTUN) untuk penyelesaian sengketanya. Penyelesaian sengketa tata usaha negara diatur di dalam Undang-Undang No. 5 Tahun 1986 yaitu tentang Peradilan Tata Usaha Negara. Putusan PTUN berupa menyatakan tidak sah sertipikat hak atas tanah yang diterbitkan oleh Kantor Pertanahan Kabupaten atau Kota. Atas dasar putusan PTUN tersebut, pihak yang dimenangkan mengajukan permohonan pembatalan sertipikat hak atas tanah kepada Kepala BPN RI.

Kelima, Penyelesaian sengketa perdata, apabila di dalam penerbitan sertipikat hak atas tanah terdapat suatu cacat prosedur maupun terdapat perbuatan yang melanggar hukum, maka pihak-pihak yang merasa dirugikan atas diterbitkannya sertipikat hak atas tanah dapat mengajukan gugatan ke Pengadilan Negeri yang wilayah kerjanya meliputi letak tanah yang bersangkutan. Penyelesaian sengketa perdata atas terbitnya suatu sertipikat hak atas tanah berpedoman pada Burgerlijk Wetboek atau BW.

Keenam, Penyelesaian perkara pidana, apabila dalam penerbitan sertipikat hak atas tanah terdapat tindak pidana oleh seseorang, misalnya ada unsur penipuan, penyerobotan, keterangan palsu, maka pihak yang dirugikan dapat melaporkan adanya tindak pidana ke kepolisian setempat. Penyelesaian perkara pidana atas diterbitkannya sertipikat hak atas tanah berpedoman pada Kitab Undang-Undang Hukum Pidana (KUHP).

Penyelesaian sengketa atas tanah terkait dengan terbitnya sertipikat hak atas tanah dapat ditempuh melalui 2 (dua) cara, yaitu: Litigasi, penyelesaian sengketa tanah dengan cara mengajukan gugatan ke pengadilan. Kalau sengketanya bersifat keperdataan, maka gugatan diajukan kepada Pengadilan Negeri (PN). Kalau sengketanya bersifat tata usaha negara, maka gugatan diajukan kepada PTUN; Non Litigasi, penyelesaian sengketa tanah di luar oleh para pihak yang bersengketa melalui jalur negosiasi, mediasi, rekonsiliasi, dan arbitrase.

Pembatalan suatu sertipikat hak atas tanah yang diterbitkan oleh Kantor Pertanahan Kabupaten/Kota dapat ditempuh melalui 2 (dua) cara, yaitu: Pertama, Pembatalan sertipikat hak atas tanah kepada Kepala BPNRI. Pembatalan sertipikat hak atas tanah dapat diajukan oleh pihak yang dirugikan kepada Kepala BPNRI karena adanya cacat hukum administratif. Pembatalan sertipikat hak atas tanah diatur dalam Peraturan Menteri Negara Agraria atau Kepala BPN RI No. 9 Tahun 1999 tentang Tata Cara Pemberian dan Pembatalan Pemberian Hak atas Tanah Negara dan Hak Pengelolaan. Cacat hukum administratif, meliputi: Kesalahan prosedur; Kesalahan penerapan peraturan perundang-undangan; Kesalahan subyek hak; Kesalahan obyek hak; Kesalahan jenis hak; Kesalahan perhitungan luas; Terdapat tumpang tindih hak atas tanah; Data yuridis atau data fisik tidak benar; atau Kesalahan lainnya yang bersifat hukum administratif. Penanganan kasus, sengketa, konflik, dan perkara pertanahan diatur dalam Peraturan Kepala BPN RI No. 3 Tahun 2011 tentang Pengelolaan, Pengkajian, dan Penanganan Kasus Pertanahan.

Kedua, Pembatalan atas sertipikat hak atas tanah melalui gugatan ke pengadilan. Pihak yang merasa dirugikan atas diterbitkan sertipikat hak atas tanah mengajukan gugatan ke Pengadilan Negeri apabila sengketanya bersifat keperdataan, atau gugatan ke PTUN apabila sengketanya bersifat tata usaha negara. Atas dasar putusan pengadilan yang telah mempunyai kekuatan hukum tetap, maka pihak yang dimenang 
dalam putusan pengadilan mengajukan permohonan pembatalan sertipikat hak atas tanah kepada BPNRI.

\section{PENUTUP}

\section{Kesimpulan}

Sertipikat hak atas tanah yang diterbitkan Kantor Pertanahan Kabupaten atau Kota merupakan tanda bukti hak yang bersifat kuat, berisi salinan buku tanah yang memuat data fisik dan data yuridis yang memuat data fisik. Dengan diterbitkan sertipikat hak atas tanah dengan mudah dapat dibuktikan bahwa orang atau badan hukum yang namanya tercantum dalam sertipikat adalah pemegang haknya.

Dengan diterbitkan sertipikat hak atas tanah akan terwujud jaminan kepastian hukum, yang meliputi kepastian status hak atas tanah, subyek hak atas tanah, dan obyek hak atas tanah. Juga terwujud perlindungan hukum, yaitu pemilik tanah atau pemegang hak atas tanah merasa aman, tenang, nyaman, tidak mendapat gangguan atau gugatan oleh pihak lain.

Sertipikat hak atas tanah yang diterbitkan oleh Kantor Pertanahan Kabupaten atau Kota sebagai tanda bukti hak yang bersifat kuat, maka masih dapat dibatalkan atas dasar putusan Pengadilan Negeri yang sengketanya bersifat keperdataan atau PTUN yang sengketanya bersifat tata usaha negara. Pembatalan sertipikat hak atas tanah juga dapat diajukan oleh pihak yang dirugikan kepada Kepala BPNRI karena ada cacat hukum administratif.

\section{Rekomendasi}

Sertipikat hak atas tanah yang diterbitkan oleh Kantor Pertanahan Kabupaten dan atau Kota bukan sebagai alat bukti yang mutlak, karena bisa dilakukan pembatalan oleh pengadilan. Oleh karena itu, Kantor Pertanahan Kabupaten atau Kota sebaiknya harus memverifikasi secara cermat persyaratan penerbitan sertipikat hak atas tanah yang diajukan oleh pemohon agar di kemudian hari tidak diajukan pembatalannya.

\section{DAFTAR PUSTAKA}

\section{Buku:}

Hajati, Sri, "Restrukturisasi Hak atas Tanah dalam rangka Pembaruan Hukum Agraria Nasional", Pidato Pengukuhan Guru Besar, Universitas Airlangga Surabaya, 5 Maret 2005.

Harsono, Boedi, 2003, Hukum Agraria Indonesia Sejarah Pembentukan Undang-Undang Pokok Agraria, Isi, dan Pelaksanaannya, Jakarta: Djambatan.

Hutagalung, Arie S., 2005, Tebaran Pemikiran Seputar Masalah Hukum Tanah, Jakarta: Lembaga Pemberdayaan Hukum Indonesia.

Lubis, Mhd. Yamin dan Abd. Rahim Lubis, 2008, Hukum Pendaftaran Tanah, Bandung: Mandar Maju.

Parlindungan, A.P., 1999, Pendaftaran Tanah di Indonesia, Bandung: Mandar Maju

Perangin, Effendi, 1989, Hukum Agraria di Indonesia: Suatu Telaah dari Sudut Pandang Praktisi Hukum, Jakarta: Rajawali.

Santoso, Urip, 2010, Hukum Agraria dan Hak-hak atas Tanah, Jakarta: Kencana Prenada Media. ,2011, Pendaftaran dan Peralihan Hak atas Tanah, Jakarta: Kencana Prenada Media.

Sumardjono, Maria S.W., 2005, Kebijakan Pertanahan antara Regulasi dan Implementasi, Jakarta: Penerbit Buku Kompas.

\section{Peraturan Perundang-undangan:}

Undang-Undang No. 5 Tahun 1960 tentang Peraturan Dasar Pokok-Pokok Agraria.

Peraturan Pemerintah No. 24 Tahun 1997 tentang Pendaftaran Tanah.

Peraturan Menteri Negara Agraria/Kepala Badan Pertanahan Nasional No. 3 Tahun 1997 tentang Ketentuan Pelaksanaan Peraturan Pemerintah No. 24 Tahun 1997 tentang Pendaftaran Tanah.

Peraturan Menteri Negara Agraria/Kepala Badan Pertanahan Nasional No. 9 Tahun 1999 tentang Tata Cara Pemberian dan Pembatalan Pemberian Hak atas Tanah Negara dan Hak Pengelolaan. 